\title{
Monetary Effects of Inequality: Lessons from the Euro Experiment
}

\author{
Antonio Filippin*1 and Luca Nunziata ${ }^{\dagger 2}$ \\ ${ }^{1}$ University of Milan and IZA \\ ${ }^{2}$ University of Padua and IZA
}

July 16, 2018

\begin{abstract}
We propose a new explanation for the decoupling of official and perceived inflation based on relative consumption concerns. In presence of high inequality, when the consumers' reference point of consumption is more distant to reach, a tight budget constraint is likely to be misperceived as a currency's loss of purchasing power. Using data from a set of 15 European countries in the period 1990-2008, we estimate the effect of inequality on inflation perception. Our research design exploits the exogenous variation in inequality induced by the reduction in social expenditure that accompanied the implementation of the convergence criteria set up by the Maastricht treaty, in the years preceding the Euro changeover. Our results confirm that an increase in inequality significantly affects the deviation of inflation perceptions from actual inflation.
\end{abstract}

Keywords: Inflation perception, Inequality, Consumption, Saving, Social Expenditure, Euro

JEL Classification Numbers: E31, E21, E03, D63.

\footnotetext{
${ }^{*}$ Corresponding author; Department of Economics, University of Milan, Via Conservatorio 7, 20122 Milano, Italy, e-mail: antonio.filippin@unimi.it

${ }^{\dagger}$ Department of Economics, University of Padua, Via del Santo 33, 35121, Padua, Italy, e-mail: luca.nunziata@unipd.it.
} 


\section{Introduction}

What drives inflation perceptions? And how can inflation perceptions diverge from actual inflation dynamics? These are relevant questions for the policy maker. When perceptions diverge from actual inflation, they may have real economic effects if for instance they map into inflation expectations (Fluch and Stix, 2005; Blanchflower and Kelly, 2008). Moreover, a misperception of price dynamics can cause suboptimal consumption decisions and more generally a misallocation of resources.

One of the most paradigmatic example of how inflation perceptions may deviate from actual inflation is certainly what observed in Europe in the 2000s. A stunning increase in inflation perceptions has been observed in the Euro zone, as documented by Figure 1, while official statistics exclude that an actual increase in prices of that magnitude took place in the same years (Gaiotti and Lippi, 2004; Adriani et al., 2009; Angelini and Lippi, 2008). ${ }^{1}$ Many explanations have been provided for why inflation perceptions could have overestimated price variations around and after the changeover, ranging from price dynamics of frequently purchased items (Del Giovane and Sabbatini, 2008), to the role played by large price hikes of single items (Malgarini, 2009), to fallacies in the recollection of prices in pre-Euro national currencies (Cestari et al., 2008; Ehrmann, 2006). Although significant, the role played by such factors does not appear to account for the entire magnitude of the decoupling between measured and perceived inflation (Marini et al., 2007), leaving room for additional interpretations.

We propose a novel behavioral explanation of why inflation perceptions may systematically diverge from actual inflation, based on relative consumption concerns and inequality. The rapid increase in the technological content of consumer goods and the rise in inequality experienced by most OECD countries in the past decades (Atkinson et al., 2011) have triggered new benchmarks for consumerism, mainly induced by the increasingly comfortable consumption patterns of the wealthiest part of the income distribution. This mechanism is based on the diffusion of positional goods that generate an increasing desire for emulation and consumption of such goods in the whole income distribution.

Several contributions in the literature investigate the effects on consumption decisions of this

\footnotetext{
${ }^{1}$ Similarly, Caporale and Kontonikas (2009) find that steady state inflation does not change after the introduction of the Euro and that in some EMU countries the link between inflation and inflation uncertainty breaks down before the changeover.
} 
phenomenon, which is popularly referred to as "keeping up with the Joneses." We posit that relative consumption concerns might also have monetary consequences. Consumers may find themselves increasingly budget-constrained in relation to the larger or more expensive bundle of goods they may desire to consume, while not being able to do so. They may then attribute their insufficient purchasing power to price inflation rather than to the relative worsening of their economic conditions compared to their typically richer reference group. This mechanism can be driven by an aspiration level of consumption well beyond the optimal consumption patterns justified by permanent income, and may affect consumers located along the whole income distribution.

In this paper we provide an empirical investigation of whether this is the case by analyzing the effect of inequality on inflation perceptions' dynamics. However, testing the causal effect of inequality on inflation perception is not an easy task. Both phenomena may be driven by common third factors and a positive correlation of inflation perception and inequality may simply reflect the effect of omitted variables. For this reason, we adopt an instrumental variable research design by exploiting the natural experiment represented by the ratification of the Maastricht treaty in 1992 and the exogenous change in social expenditure and inequality that followed in many signatory countries.

Social expenditure cuts have been shown to significantly correlate with an increase in inequality. For instance, using a panel of 18 industrialised countries, Agnello and Sousa (2013) show that fiscal consolidation periods, when social expenditure is generally reduced, are generally associated with an increase in income inequality. Similar evidence is provided by Ball et al. (2013) and Woo et al. (2013), who also point out that spending cuts have larger distributional effects than tax-based adjustments. Bertola (2010) suggests that the European Monetary Union was associated with a small but significant increase in disposable income inequality, accounted for by cuts in social policies. Concurring evidence is shown by Bouvet (2010), who reports an increase in within-country inequality (as measured by the Theil index) of about $11 \%$ due to the implementation of the Stability and Growth Pact in the period 1997-2003.

Our research design consists in estimating a three equations model, in which inflation perceptions are explained by income inequality (plus actual inflation and other controls) on data from 15 western European countries collected from 1990 to 2008. Our instrument for inequality is the exogenous reduction in per capita government social expenditure imposed by the Maastricht Treaty on the Euro adopting countries in order to meet the convergence criteria. The signing 
and design of the Maastricht Treaty in 1992 can be considered exogenous in the context of our analysis since the treaty was the result of the political contingencies of the time, in conjunction with the decades-long process of economic and political integration among European countries. In addition, the reasons why the non-signing countries decided not to join the Euro area were mostly related to the traditional opposition of national voters to the idea of a loss of sovereignty implied by a stricter European integration, rather than to the specific economic circumstances of the time. The implicit assumption is that the treaty had no direct impact on inequality and inflation perceptions (after controlling for actual inflation and other macroeconomic controls) other than through the fiscal consolidation that was at the core of the agreement. Since our aim is investigating the divergence between perceived and actual inflation, we control for actual inflation in all our specifications, accounting for all possible monetary factors that may be relevant to the relationship of interest. ${ }^{2}$

Our first stage regressions confirm that social expenditure has been negatively affected by the fiscal consolidation initiated by the single currency process. In addition, the second stage shows that social expenditure is indeed strongly and negatively correlated with inequality. Finally, inequality is found to have a significant and positive effect on inflation perceptions and negative on perceived savings, after controlling for actual savings. Our findings survive a number of robustness checks, including a different specification where we control for unobservable institutional country characteristics through country fixed effects.

Our contribution is novel, as it proposes an original behavioral perspective on the monetary consequences of inequality, something so far neglected in the literature. Moreover, we propose an innovative quasi-experimental research design to investigate the relationship between inequality and inflation perceptions. The paper is organized as follows: Section 2 presents the theoretical framework underlying the link between inequality and inflation perceptions. Section 3 illustrates our research design and Section 4 presents the data. Our empirical findings are discussed in Section 5. Finally, Section 6 concludes.

\footnotetext{
${ }^{2}$ We therefore indirectly control for all economic and institutional determinants of actual inflation (Bowdler and Nunziata, 2006, 2007b,a; Andersson et al., 2009).
} 


\section{Relative Consumption and Inflation Perception}

Many economists have stressed the importance of relative as opposed to absolute income levels, i.e. of income comparisons within reference groups, in explaining economic behavior. ${ }^{3}$ Recent literature has put emphasis on the negative externalities deriving from social competition based on positional goods, whose only goal is that of maintaining/improving one's own status in the social ranking. This is the so-called "keeping up with the Joneses" hypothesis. Some empirical analyses (e.g., Ferrer-i Carbonell, 2005) confirmed the importance of relative income comparisons for life satisfaction.

The "keeping up with the Joneses" phenomenon can be illustrated using the expenditure cascade model (Frank et al., 2014), that introduces a process in which increased expenditure by some individuals leads others just below them on the income scale to spend more as well. Such a mechanism captures a concern for relative consumption in the utility function and it is formalized as:

$$
C_{i}^{*}=(1-a) k Y_{i}+a C_{i+1}
$$

where $C_{i}^{*}$ indicates the aspiration level of consumption of the $i$ th consumer and $Y_{i}$ denotes her permanent income levels, while $C_{i+1}$ represents the current consumption level of the individual whose permanent income ranks just ahead of $i$ 's own. $k$ is the fraction of permanent income spent, and $a$ is the parameter weighting the influence of higher income consumers' spending.

This step by step comparison enables the richest top percentiles in the income distribution to influence the rest of the consumers by inducing more expensive patterns in desirable consumption. A direct implication is a decrease in savings that might induce dynamic inefficiencies in terms of a decline in future consumption. Another feature of this model is that the concern for relative consumption magnifies the economic role played by inequality. ${ }^{4}$

We believe that "keeping up with the Joneses" triggers monetary consequences, too. The effort

\footnotetext{
${ }^{3}$ Veblen (1899) introduced the concept of "conspicuous consumption," attributing a status-seeking function to consumption activities. The "relative income hypothesis" was later on formulated by Duesenberry (1949), who stressed the asymmetric and upward nature of social comparisons, while Hirsch (1976) identified the category of "positional goods," i.e. goods from which the individual derives utility in relative terms, in the sense that their ownership defines the individual position in the social hierarchy.

${ }^{4}$ Aspiration levels of consumption have also been analyzed under a Prospect Theory framework, in order to investigate their dynamic effect on economic growth, in relation to inequality (Bogliacino and Ortoleva, 2015; Genicot and Ray, 2017).
} 
necessary to match the consumption level of the reference group, or the inability of doing so, can generate a feeling of financial distress that is likely to be confounded with a loss of purchasing power, thereby affecting inflation perceptions. Such a mechanism is consistent with a form of self-serving bias, i.e. the tendency to blame external factors as responsible for negative outcomes in order to preserve one's self esteem. ${ }^{5}$ In case of the monetary effects of "keeping up with the Joneses," consumer's loss of purchasing power in relative terms would be attributed to a change in prices (external condition), rather than to the deterioration of her/his relative economic and social status.

A natural objection to this argument regards the reason why agents should misperceive the change in prices since detailed and objective statistics about inflation are readily available to the public. What makes possible (and likely) such a misperception is that the variation in the Harmonised Index of Consumer Prices (HICP) only accounts for price changes of a given bundle of goods, and not for a change in the value of such bundle in absolute terms. Consequently, a consumer who is compensated for the variation in inflation, can maintain a constant standard of living but cannot sustain an increasing one. ${ }^{6}$

In contrast, the concept of an acceptable standard of living in a mature economy is dynamic in nature and likely to adjust over time according to factors such as technological progress, social habits and role models. According to hedonic adaptation theory, the higher well-being linked to increased income wears off with time, because individuals adjust their aspirations upward proportionally to the increase in income. ${ }^{7}$ As a result, dynamic aspirations make for an almost constant level of happiness during the life cycle. This process is often described by the metaphor of the hedonic treadmill introduced by Brickman and Campbell (1971). Kahneman et al. (2004) distinguish instead between an hedonic treadmill depending on adaptation, and a satisfaction treadmill depending on aspiration. If aspirations are shaped by a social comparison, the metaphor becomes that of a "social treadmill" (Stutzer, 2004; Bruni, 2009). Positional goods are first consumed by the wealthiest part of the population and then they tend to be consumed

\footnotetext{
${ }^{5}$ This cognitive bias has been studied extensively in social psychology (see Mezulis et al., 2004, and references therein) and has been detected in various decision frameworks, including consumer choice (Moon, 2003).

${ }^{6}$ The HICP tracks the price change of a basket of goods the value of which is supposed to be constant in real terms. When obsolete items are replaced with modern and more valuable counterparts (e.g. the compass with the GPS locator) the weights of the items in the basket are revised. The revised weights, however, count only toward the aggregation of future price changes, but not as far as the value of the basket is concerned. In other words, the mere substitution of the compass with the GPS locator does not alter the level of the index.

${ }^{7}$ For instance, Di Tella et al. (2010) show that most of the current year's impact of an increase in income on happiness is lost over the following four years.
} 
more and more across the whole income distribution. Not possessing such a good, when its possession spreads among consumers, generates an increasing feeling of relative deprivation. Such a mechanism can therefore rationalize why a higher consumption level in absolute terms may not be perceived as an increasing standard of living, or why a constant consumption level in presence of higher income inequality may be perceived as a distress.

We present the monetary counterpart of "keeping up with the Joneses" as an overestimation of inflation whenever real incomes do not increase harmonically with desired consumption patterns. Such a mechanism is captured by an inflation perception equation that includes an aspiration level of consumption $C_{i}^{*}$ derived in a similar manner as in Equation (1), which internalizes relative consumption concerns:

$$
\tilde{\pi}_{i}=\pi+\alpha f\left(C_{i}^{*}-C_{i}^{Y}\right)
$$

Defining $\tilde{\pi}_{i}$ the individual perception of the actual inflation $\pi$, the difference between perceived and measured inflation is supposed to be affected by the gap between the aspiration level of consumption and the optimal consumption level $C_{i}^{Y}$ generated by any level of permanent income $Y$ in absence of any social comparison.

When the the aspiration level $C_{i}^{*}$ increases, agent $i$ is induced to change her/his consumption patterns through an increase in consumption expenditure over the optimal level. Alternatively, in presence of budget or liquidity constraints the agent perceives a relative deprivation effect since the aspiration level of consumption is not met. For example, if my neighbour buys a brand new car, I am induced to do the same, and in order to do so I may cut savings. As a result, I may perceive that the costs of living have increased and I may wrongly attribute that to the loss of purchasing power due to inflation. Alternatively, in presence of liquidity constraints or other reasons that prevent me from buying the new car, I will suffer a disutility due to the increased distance between my actual consumption pattern and that of my neighbour. In this case the consumption gap would be perceived as a constraint in my spending capacity that I may wrongly attribute to rising inflation. In both cases (decrease of savings and foregone consumption) what matters is that the gap between my aspiration consumption level and the optimal consumption pattern given my permanent income widens.

This mechanism relies on two implicit assumptions. First, each household's actual consumption is affected by the consumption pattern of its reference group. Second, the insufficient purchasing 
power is wrongly attributed to higher prices rather than to a lower relative income.

As regards the first point, micro data evidence provided by the European Social Survey (see Table A.1 in the Appendix) shows how the importance of being rich, have money and expensive things, i.e. to follow the consumption patterns of richer consumers, is evenly distributed among European residents across the whole income distribution, with only a significant difference for the 5th and top decile when compared to the first. This means that the desire to acquire expensive things is pretty homogeneous across income deciles, irrespectively of the actual consumers' purchasing power. If such desire is not matched by the ability to afford a sufficiently affluent consumption pattern, consumers might feel frustrated. Such frustration is likely to increase in presence of growing inequality due to the consequent shift in consumers' reference point.

A testable implication of the second point is that economic distress should exacerbate inflation misperceptions. Del Giovane et al. (2008) document that the divergence between perceived and actual inflation is indeed stronger for individuals characterized by a relatively worse financial situation, even after controlling for literacy and educational levels. ${ }^{8}$ Different inflation perceptions across the income distribution are not driven by exposure to different levels of actual inflation, that has been shown to be pretty homogeneous across income deciles. For example, Del Giovane and Sabbatini (2008) estimate the inflation rate by class of expenditure in 2002 and 2003. Considering the distribution by consumption pattern for each segment of population, the reported differences in actual inflation across income deciles are indeed negligible. Eurostat data show that inflation perceptions tend to overestimate measured inflation across the whole income distribution, although being exacerbated by economic distress. This evidence supports the idea that the mismatch between desired and actual consumption is present also among high income quantiles.

\section{Research Design}

An ideal empirical test of Equation (2) would require to check how individual inflation perceptions react to individual actual and foregone consumption patterns. However, it is hard to identify a reference group that could simulate the unobservable aspiration level of consumption

\footnotetext{
${ }^{8}$ Lindén (2005) shows that the gap between measured and perceived inflation tends to be smaller for individuals with higher education.
} 
at the individual level. We therefore choose to conduct an empirical investigation of the effect of interest through a different strategy, by concentrating on the actual driver of social comparison at the aggregate level, i.e. inequality.

By definition, an increase in inequality signals a disharmonic change in income levels, that is accompanied by an increased gap between the consumption patterns of economic agents and their reference group. The mechanism above is absent, by construction, in hypothetical societies where there is no inequality. On the contrary, when incomes grow at a much slower pace than what needed to fulfil the aspirations driven by social comparison, individuals may feel budget constrained and perceive a loss of purchasing power even though they are not impoverished in absolute terms. As a result, an increase in inequality may contribute to a misperception of the true inflation level.

Our analysis will therefore focus on the link between inequality and inflation perceptions at the aggregate level. Our baseline estimated model will be:

$$
\tilde{\pi}_{i t}=\beta_{0}+\beta_{1} I_{i t}+\beta_{2} \pi_{i t}+\beta_{3} X_{i t}+\lambda_{t}+\epsilon
$$

where $\tilde{\pi}, I$ and $\pi$ are, respectively, aggregate measures of inflation perceptions, inequality and actual inflation at the country $(i)$ and year $(t)$ level, $X$ represents a vector of controls, including a dummy for the actual introduction of the Euro currency, $\lambda_{t}$ a set of year fixed effects and $\epsilon$ is a stochastic term.

In the last decades a widespread increase in economic inequality has been observed in advanced economies (Piketty and Saez, 2003; Atkinson et al., 2011; Bogliacino and Maestri, 2014; Tóth, 2014). If our conjecture is correct, the higher inequality, the stronger the relative deprivation felt by consumers along the whole income distribution. The increase in relative deprivation should have deteriorated their perceived purchasing power, which may then wrongly be attributed to increasing prices, thus increasing their inflation perceptions.

European data are particularly suited for our analysis since it has been shown that inequality has a higher impact on individual happiness in Europe than in the US (Alesina et al., 2004). Figure 2, drawn for the major 15 European countries in the period 1990-2008, shows how inequality, measured by a Gini index, is positively correlated with inflation misperceptions, i.e. 
with the residuals of a regression of inflation perception on actual inflation and time dummies. ${ }^{9}$ In the figure we notice two clusters of countries, characterized by different levels of inequality with Mediterranean countries and the UK typically associated with higher levels of inequality than the rest of Europe. The misperception of inflation is systematically higher when inequality is higher, and viceversa. The positive association is confirmed by OLS estimates of the same model (not reported).

Such association may however be confounded by unobservable factors affecting both inequality and inflation perceptions. For example, in a scenario characterized by rising inequality and expectations of strong future GDP growth, inflation perceptions may anticipate actual changes in inflation growth, therefore generating a spurious correlation between inequality and perceptions. Ideally, we would need an exogenous shift in a suitable instrument that would, in turn, trigger a change in inequality in an experimental fashion, in order to check its causal implications in terms of inflation perceptions.

One candidate instrument is an exogenous shift in social expenditure, a variable which is typically associated with lower inequality, as shown for instance by Bertola (2010) and Niehues (2010). This correlation is confirmed by our data on EU-15 countries as we can see from Figure 3. However, social expenditure is not necessarily exogenous in a model of inflation perception. We need therefore to identify a change in policies that is not directly correlated to the factors behind inflation perception and that may generate such an exogenous change in social expenditure. To this aim, we exploit the natural experiment of history constituted by the process of implementation of the Euro currency, and in particular the different treatment status between Euro-adopting and non-adopting countries. The idea is that the fiscal tightening that accompanied the Maastricht treaty was larger in the first group of countries in the years preceding the Euro changeover, thereby inducing an exogenous change in social expenditure, with a resulting increase in inequality. ${ }^{10}$

Figure 4 plots the difference between the per capita social expenditure in each country subject to the Maastricht Treaty budget constraints, and the average of those that did not signed the treaty. Our treatment group of Euro-adopting countries that were affected by exogenous social expenditure cuts compared to non adopting countries include Austria, Belgium, Finland,

\footnotetext{
${ }^{9}$ For details on data construction, see Section 4 below.

${ }^{10}$ Following Heckman (2000), our approach is in the tradition of using natural social experiments to identify the causal effect of interest.
} 
France, Germany, Greece, Ireland, Italy, Spain, Netherlands and Portugal. The effect of the tightening in per capita social expenditure is clearly visible and it appears to persist until 2008, although the largest reduction took place in the years preceding the changeover. The only Euro adopting country that does not show any appreciable reduction in social expenditure compared to the non-adopting countries is Luxembourg, where we observe an increase from 1990 to 2008.

An implication of the constraint on public finances, and on social expenditure in particular, was an increase in inequality that was not limited to those countries that were hit by the major adjustments (Bertola, 2010). We can therefore exploit the change in inequality triggered by an exogenous reduction in per-capita social expenditure to estimate the effect of inequality on inflation perceptions. ${ }^{11}$

Our baseline model will therefore consist in estimating equation (3) through a 3SLS procedure where the signing of the Maastricht Treaty in 1992 induces a quasi-experimental manipulation in social expenditure in the signing countries due to the convergence criteria compared to the non signing countries (first stage). Such change may exogenously affect inequality (second stage) that in turns may shape inflation perceptions (third stage). We then perform a series of robustness checks on our baseline model, including testing whether our findings survive after we include a series of additional controls, when we use alternative measures of social expenditure, and whether our findings depend on the inclusion of specific countries (adopting and non-adopting) in the sample. We also check whether our findings are robust to a change in specification where we estimate equation (3) including country fixed effects though a 2SLS procedure.

Our identification strategy relies on the assumption that the implementation of the Maastricht Treaty had no direct impact on inequality and inflation perceptions (after controlling for actual inflation) other than through the fiscal consolidation that was at the core of the agreement. This assumption would be invalid if countries decided to adopt the single currency on the basis of inflation perception or inequality concerns. However, the signing and design of the Maastricht Treaty in 1992 was largely the result of the political contingencies of the time in conjunction with the post-World War II historical process of economic and political integration among European countries. The control group of non-adopting countries that were not subject to such restrictions on fiscal policies include Denmark, Sweden and the United Kingdom. These countries decided

\footnotetext{
${ }^{11}$ This approach is similar to the strategy adopted by Becker and Woessmann (2009) in estimating the effect of Protestantism on literacy and economic performance in 19th century Prussia.
} 
not to join the Euro area for political motives that are likely to be exogenous in our model. At the time, a large fraction of UK voters was traditionally eurosceptic and considered the single currency a dangerous step toward a tighter political integration in Europe and a consequent loss of sovereignty that they firmly rejected. ${ }^{12}$ Similar concerns were voiced in Denmark and Sweden. Denmark negotiated the possibility to stay out of the common currency under the Maastricht Treaty through the exceptions included in the Edinburgh Agreement signed in December 1992, whereas Sweden decided not to comply with the treaty convergence criteria that included as a precondition the adoption of the European Exchange Rate Mechanism. A referendum on the introduction of the Euro was defeated in both countries, in 2000 and 2003 respectively.

Furthermore, the characteristics of both adopting and non adopting countries vary considerably in terms of average pre-treaty inequality and social expenditure. If we look at the data on social expenditure in the early 1990s, i.e. before the Maastricht Treaty's effects on adopting countries became visible, we do not see any peculiar pattern of non adopting countries when compared to non adopting countries. ${ }^{13}$ Similarly, inequality tend to be low in Denmark and Sweden, but also in Belgium, Finland, and the Netherlands. This is further indication that the choice of staying in or out of the single currency was not related to social expenditure or inequality patterns.

Our sample years, comprised between 1990 and 2008, are a suitable period to analyze the effects of the Euro experiment on inequality and in turn on inflation perceptions. Indeed, the fiscal tightening started after the Maastricht treaty was signed in 1992 and reached its peak at around 2000 just before the currency changeover. ${ }^{14}$ We prefer to exclude the years following 2008 to eliminate the global financial crisis' confounding effect. Nevertheless our findings are robust to the inclusion of those years, given that all our specifications control for year fixed effects.

\footnotetext{
${ }^{12}$ This attitude was confirmed more than two decades later by the "Brexit" referendum results in June 2016.

${ }^{13}$ The picture on per-capita social expenditure levels in adopting and non adopting countries was mixed, as in the rest of our sample years. The two countries characterized by the highest level of per-capita social expenditure were Denmark and Luxembourg. Sweden was in line with the Northern European adopting countries, while the UK displayed a very low level of social expenditure, comparable to the adopting mediterranean countries.

${ }^{14}$ The Council's assessment $(98 / 317 / C E)$ on the fulfilment of the convergence criteria was based on the figures of the fiscal year 1997. It is worth noting that the Maastricht criteria have to be fulfilled on a permanent basis, and therefore the fiscal tightening could not be easily reversed afterwards.
} 


\section{The Data}

Our analysis is based on data collected for the group of EU-15 countries. Our dataset includes the countries that introduced the Euro coins and bills in 2002 (Austria, Belgium, Finland, France, Germany, Greece, Ireland, Italy, Luxembourg, the Netherlands, Portugal and Spain), as well as those countries that did not adopt the single currency (Denmark, Sweden and the UK). The data cover the period 1990-2008 from different data sources. In what follows we describe all the variables used in our estimates. Summary statistics are provided in Table 1.

\section{TABLE 1 AROUND HERE}

The data on Inflation perceptions are derived from representative surveys at the national level, collected monthly by national institutes of the EU Member States on behalf of the European Commission (DG ECFIN) as part of the Joint EU Harmonised Programme of Business and Consumer Surveys (EC, 2014). More than 20,000 subjects every month answer to the question "How do you think that consumer prices have developed over the last 12 months?" by choosing among different categories:

1. risen a lot;

2. risen moderately;

3. risen slightly;

4. stayed about the same;

5. fallen.

As commonly done in the literature (Ehrmann, 2006; Biau et al., 2010), our proxy for inflation perceptions is an aggregate measure of consumers' opinions derived as the difference in the weighted frequency $f()$ of answers falling in different categories according to the formula:

$$
\text { Infl.Perc }=f(1)+\frac{1}{2} f(2)-\frac{1}{2} f(4)-f(5) .
$$

As shown by Biau et al. (2010), this variable is highly correlated with the inflation perception measure published by the ECB from 2003 only, i.e. not covering our period of interest. Our perceived inflation measure varies between a minimum of -58.4 and a maximum of 77.7 .

Actual inflation is calculated using the Harmonised Index of Consumer Prices (HICP) inflation rate, year over year, released monthly by Eurostat. 
Our measure of inequality is the Gini index computed on disposable incomes as provided by the Standardized World Income Inequality Database (SWIID) (Solt, 2009). The Gini index is calculated yearly and varies between 21.6 and 36.9 in our sample with some variability both within and between countries. One of the advantages of the SWIID data, is that it provides the possibility to perform additional estimations using multiply imputed data methods, in order to take into account the uncertainty associated with the construction of the inequality data by country.

Social expenditure is measured by social protection benefits per capita at constant 2000 prices (source: Eurostat). We consider expenditure for sickness and disability, old age and survivors, housing and social exclusion, unemployment and families and children as well as excluding social expenditure for unemployment in some regressions. Original data are provided on a yearly basis. Taking logs, our measure varies between 7.6 and 9.7 in our sample. For a robustness check we also consider social expenditure expressed as a share of GDP.

We also provide additional analysis of the effect of inequality on perceived savings. The aforementioned Joint EU Harmonised Programme of Business and Consumer Surveys also asks subjects "Which of these statements best describes the current financial situation of your household?". Aggregate self-reported ability to save is derived as the difference in the cumulative frequency of those who answer "we are saving a lot," or "we are saving a little" minus those who answered "we are having to draw on our savings," or "we are running into debt." Note that this variable does not capture actual savings but a perceived measure of savings that may reflect a comparison between actual and desired level of consumption.

Our specifications include a set of macroeconomic controls. The actual net household saving rate is provided by the OECD System of National Accounts and it is defined as "the subtraction of household consumption expenditure from household disposable income, plus the change in net equity of households in pension funds". It is measured as percentage of household disposable income. Unemployment and real GDP growth are also provided by the OECD. Other controls include house price inflation, from the OECD, and an indicator of the country's general participation in tertiary education, measured as the number of students enrolled in tertiary education in a given academic year per 100,000 inhabitants, from the Barro and Lee (2010) dataset. In order to control for trade specialization patterns that may be affected by the tighter economic integration induced by the Maastricht Treaty, we use a measure of fixed capital formation as a share of GDP from Eurostat, and a Hirschman-Herfindahl Index (Herfindahl, 
1950; Hirschman, 1964) from the World Integrated Trade Solution dataset, assembled by the World Bank in collaboration with United Nations Statistical Division and the World Trade Organization.

\section{$5 \quad$ Empirical Findings}

\subsection{SLS Estimates}

Table 2 presents our baseline Three Stages Least Squares (3SLS) estimations that display the effect of the Maastricht Treaty on per capita social expenditure, the implications of expenditure cuts on income inequality and the effect of inequality on inflation perception. All models are estimated using a Limited Information Maximum Likelihood (LIML) estimator that is characterized by good small sample properties even if instruments are weak. All models control for the actual introduction of the Euro coins and bills in January 2002. This is an important test for our analysis, since Figure 1 shows that the decoupling between actual and perceived inflation in the Euro area increase dramatically after 2002, and this may confound our estimates since year fixed effects are not enough to account for it. We therefore include a dummy variable equal to 1 starting from 2002 in the adopting countries, that may account for the effect of consumers' confusion or approximation about the conversion rates between pre-Euro national currencies and the single currency. ${ }^{15}$

We first present our preferred baseline specification, in columns (1)-(3), where we control for actual inflation, unemployment, and GDP growth, time dummies and a Euro introduction dummy equal to 1 for all adopting countries after 2002, i.e. excluding any potentially endogenous variable from the specification. Each column in the table represents one of the estimated equations.

We see in column (1) that the effect of the Maastricht Treaty, i.e. a dummy equal to 1 for the signing countries from 1992 onward, was a significant reduction in social expenditure. Such exogenous reduction in social spending that took place in the fiscal consolidation phase following the signing of the treaty correlates with an increase in inequality (column 2), and the latter is

\footnotetext{
${ }^{15}$ Consumers were directly exposed to the conversion rates only a few months before the actual introduction of the Euro in 2002, with the introduction of double prices (in local currency and in Euro).
} 
found to induce an increase in inflation perception (column 3).

The second model, presented in columns (4)-(6), includes an additional macroeconomic control, i.e. the actual household saving rate, that is not available for some country/year cells. Our sample is therefore sensibly reduced to 206 observations, but our results are unchanged and the point estimate of the effect of interest is actually even larger.

All systems of equations in the table show that an exogenous shift in inequality positively affects inflation perceptions, with the point estimates indicating that a unitary increase in the Gini index being associated with an increase in the inflation perception index comprised between 2.2 and 2.5. This corresponds to an increase in inflation perceptions between 9.2 and 10.5 for an increase in inequality equal to a standard deviation in the sample. In comparison, the actual introduction of the Euro currency in 2002 is associated with an increase in inflation perception comprised between 38 and 45, i.e. still large even after accounting for the effect of inequality. This means that the actual introduction of the single currency in the adopting countries did constitute a dramatic shock on perceptions and that the dynamics in inflation perceptions are more complex than what the simple plot in Figure 1 may suggest, since the role of inequality remained hidden by the large and significant impact of the changeover. The F-statistics exclude the presence of weak instruments in all our regressions.

\section{TABLE 2 AROUND HERE}

In Table 3 we provide a set of robustness checks. For convenience, in this table we only present our third stage and the F-statistics of weak instruments for the first and second stage. One possible concern for our identification is that social expenditure may affect inflation perception through the stability of consumption patterns, irrespectively of inequality. For instance, even those individuals who do not directly benefit from social expenditure might choose a higher consumption level because they know that they would somehow be protected by the social safety net in case of a negative shock. By doing so, social expenditure may help reducing the gap with their consumption aspiration level, thereby reducing their inflation perceptions. We therefore estimate our model using a measure of social expenditure that excludes unemployment benefits, i.e. the most important income support measure for households hit by negative labour market shocks. In addition, unemployment benefits are a social expenditure component that usually responds to the business cycle and therefore may introduce some endogeneity in our measure. 
Although in our regressions social expenditure is instrumented and we do control for the cycle through year fixed effects, we re-estimate our model excluding unemployment benefits. Column (1) presents the resulting effect of inequality on inflation perception. The point estimate of the effect of interest is equal to 2.2 and still statistically significant. The F-statistics show that we can safely exclude the hypothesis that our instruments are weak.

In column (2) we include a measure of fixed capital formation, expressed as a share of GDP, to control for different degrees of capital intensity across countries and account for the potential heterogeneous effects of trade and specialization patterns induced by the promotion of further economic integration after the treaty's signature. Our effect of interest is robust to the inclusion of this control. Our findings are also robust when we include an Hirschman-Herfindahl Index that measures market concentration and specialization (Herfindahl, 1950; Hirschman, 1964), as displayed in column (3). ${ }^{16}$

In column (4) we control for education as a proxy for financial literacy, since it is possible that the mismatch between actual and perceived inflation may be mediated by the agents' ability to process the available economic information on the topic, as suggested by Lindén (2005). Our effect of interest is still significant and an increase in education is associated with a smaller mismatch between actual and perceived inflation, as expected.

In column (5) we control for housing price inflation. Indeed, our sample years were characterized by fast increases in housing prices in many countries due to the relative low cost of borrowing. Such dynamics typically increase the rental income earned by housing investors relative to other individuals, with a consequent increase in income inequality. In addition, higher housing prices may also lead to perceptions of higher inflation accompanied by greater misperceptions given that existing home prices are not included in the HICP. It follows that, in countries with higher inequality, inflation perceptions may deviate more from actual inflation simply because of higher housing prices. However, when we control for housing price our estimates are still statistically significant, and the point estimate of the effect of interest is actually larger at 3.6, possibly due to our reduced sample size, given the unavailability of house price inflation for Austria, Greece and Portugal. The coefficient of house price inflation is positively associated with inflation perception, as expected.

\footnotetext{
${ }^{16}$ When included, fixed capital formation is negatively correlated with inequality in the second stage, contrary to the prediction of the Stolper Samuelson theorem (Stolper and Samuelson, 1941), according to which income inequality should rise in countries that specialize in capital-intensive production.
} 


\section{TABLE 3 AROUND HERE}

Finally, we estimate a model in column (6) where we control for all these additional variables together. Since each control contains some missing observations, our sample gets sensibly reduced. Nevertheless, our estimates are still statistically significant. The null hypothesis of weak instruments is rejected for each model in the table. ${ }^{17}$

\subsection{Robustness Checks}

This section performs a number of robustness analyses. First, we used two alternative methods, detailed in the Appendix, for correcting for the noise in the SWIID inequality data introduced by the multiple-imputation procedure used to resolve the trade-off between comparability across countries and coverage of country/years cells. We never find any appreciable difference in our estimates when we use any of these corrections.

In addition, we used p90/10 data on disposable income, that however are severely incomplete. We replicated our analysis using imputation techniques for the missing values, finding that our results are indeed robust.

As a further robustness control, we estimate our baseline model using an alternative measure of social expenditure, expressed as share of GDP rather than per capita. This is not an ideal measure of social expenditure for two reasons. First, it is more prone to business cycle's volatility, something that may trigger changes in this explanatory variable that are unrelated to the shock induced by the Maastricht Treaty. Second, the perceived loss of purchasing power should be affected by the level of social expenditure. For our baseline model we therefore prefer a measure accounting for the average amount of social expenditure available for each national resident. Nevertheless, social expenditure as share of GDP allows us to partial out systematic differences across countries in the generosity of their welfare state, thereby limiting the pre-treaty heterogeneity in social expenditure in our sample. Therefore estimating the model including such variable may shed some light on whether such heterogeneity matters. Table 4 replicates the specifications presented in Table 2 with no appreciable difference in our findings.

\footnotetext{
${ }^{17}$ These findings are also used for an additional test of omitted variables bias based on the methodology proposed by Oster (2016). The estimated effect of inequality on inflation perception is remarkably stable to this check.
} 


\section{TABLE 4 AROUND HERE}

As a further step, we estimate the effect of inequality on perceived savings, a variable that in presence of relative consumption concerns should be similarly affected by inequality when subjects struggle to reach their aspiration level of consumption. As shown in Table 5, our estimates confirm this hypothesis. An increase in inequality is found to reduce perceived savings, with a point estimate varying between -8.8 and -6.9 when controlling for the actual household saving rate. Once we control for the actual aggregate saving rate, the estimated effect is likely to be generated by the feeling of financial distress driven by foregone consumption and it is consistent with our inflation perception estimates.

\section{TABLE 5 AROUND HERE}

We also check how our inflation perception estimates are sensitive to country exclusion, to test whether our results are driven by the presence of any specific country in the sample. This is also an indirect check of whether each country's peculiar reasons for signing the Maastricht Treaty matter for our identification. We estimate our preferred specification, i.e. the one of columns (4)-(6) in Table 2, dropping one country at a time from the sample. We drop both adopting and not adopting countries from our sample (see Table A.2 in the Appendix), finding that our estimates are remarkably stable and do not depend from the inclusion of any specific country. The estimated coefficients of inequality range between 1.5 and 3.2. Similar findings are obtained after controlling for additional macroeconomic variables or house price inflation. As a further check, we estimate our preferred specification excluding all countries belonging to the high-inequality cluster in Figure 2, i.e. the southern European countries and the UK. As a result, the sample drops to 160 observations, but the effect of inequality on perceptions is still positive and significant.

Finally, we include country fixed effects. Our design exploits the shift in social expenditure that occurred in adopting countries after 1992. Our estimates therefore are the product of the cross-sectional variability in the data generated by the country assignment to the treatment (Euro), as well as by the time series change in social expenditure that occurred after the treaty.

One limitation of our approach is that we do not control for time-invariant country specific unobservable factors through country fixed effects. One possible answer to this limitation, is 
re-writing the model as a 2SLS specification, i.e. substituting the first-stage Maastricht Treaty assignment dummy with a set of country dummies in a model where we instrument inequality with social expenditure in the first stage. This specification relies only upon the effect of a within country change in social expenditure on inequality, controlling for country-specific observable and unobservable characteristics. Such a specification responds to possible concerns related to the exclusion restrictions attached to our treatment variable, i.e. the signing of the Maastricht Treaty.

\section{TABLE 6 AROUND HERE}

Our 2SLS estimates are presented in Table 6, where we summarize the replication of the specifications presented in Tables 2 and 3. The effect of inequality on inflation perceptions is still highly significant, and the point estimates are even larger, varying between 5.5 and 13.6. The effect of the actual changeover in 2002 is smaller than what found in previous models, the coefficient being lower than 30 and not significant when we include all controls. The sign of the effect of the remaining controls is as expected, with a larger and significant coefficient for house price inflation equal to 1.5 .

\section{Concluding Remarks}

In this paper we suggest that inflation perceptions may be affected by inequality via relative consumption concerns in the attempt to imitate the role models represented by richer agents. In a scenario of growing inequality, the consumption patterns of each agent's reference point becomes more and more difficult to imitate by relatively less affluent consumers. This mechanism may take place through an increased demand of positional goods that affects the aspiration level of consumption along the whole income distribution. As a result of this "trickle-down behaviorism", in the definition by Stiglitz (2011), consumers who cannot match their aspiration level of consumption may experience a sense of frustration and financial distress that can be confounded with a loss of the currency's purchasing power, i.e. with higher inflation perceptions. This phenomenon is not confined to the less wealthy and increasingly budget-constrained portion of the income distribution, but it affects higher income percentiles as well, as agents are still subject to the influence of social comparison with a richer reference group. 
We provide a first attempt to investigate the relationship between inequality and inflation perception by exploiting the quasi-experimental change in social expenditure that was triggered by the adoption of the Maastricht treaty in 1992. We find that the reduction in social expenditure induces an increase in income inequality, as measured by the Gini coefficient of disposable income. By instrumenting inequality with an exogenous variation in per-capita social expenditure, we find that an increase in inequality causes a substantial increase in perceived inflation, after controlling for actual inflation and a number of observable and unobservable factors. In addition, inequality has a significant negative effect on perceived savings, as expected in presence of such behavioral pattern.

This mechanism based on relative consumption considerations may contribute to explain the stunning difference between actual and perceived inflation in European countries in the 2000s, although we do find that the actual changeover represented a further large shock on inflation perceptions. Official statistics have often been accused of misreporting inflation figures after the introduction of the Euro in 2002, because at odds with the European citizens' common perception that inflation grew much more than what reported. Our empirical evidence suggest that part of the decoupling may be explained by the monetary effect attached to "keeping up with the Joneses" in a period of rapidly growing inequality as before and around the currency changeover.

Our analysis provides important implications for policy making. By showing that concerns for relative consumption may have monetary consequences, our results indicates that the policy maker should take into account consumers' behavior along this perspective in order to correctly anticipate the effects of policy interventions. In particular, monetary policy may have different effects depending on the level of inequality, and any policy having an impact on inequality may be accompanied by unintended monetary consequences. 


\section{References}

Adriani, F., Marini, G. and Scaramozzino, P. (2009). The inflationary consequences of a currency changeover on the catering sector: Evidence from the michelin red guide. Oxford Bulletin of Economics and Statistics, 71 (1), 111-133. 1

Agnello, L. and Sousa, R. M. (2013). How do Banking Crises Impact on Income Inequality? Review of Income and Wealth. 1

Alesina, A., Di Tella, R. and MacCulloch, R. (2004). Inequality and happiness: are Europeans and Americans different? Journal of Public Economics, 88 (9-10), 2009-2042. 3

Andersson, M., Masuch, K. and Schiffbauer, M. (2009). Determinants of inflation and price level differentials across the euro area countries. Working Paper Series 1129, European Central Bank. 2

Angelini, P. and Lippi, F. (2008). Did prices really soar after the euro cash changeover? Evidence from ATM withdrawals. In P. Del Giovane and R. Sabbatini (eds.), The Euro, Inflation and Consumers' Perceptions, Springer, pp. 109-124. 1

Atkinson, A. B., Piketty, T. and Saez, E. (2011). Top Incomes in the Long Run of History. Journal of Economic Literature, 49 (1), 3-71. 1, 3

Ball, L. M., Furceri, D., Leigh, D. and Loungani, P. (2013). The Distributional Effects of Fiscal Consolidation. IMF Working Papers 13/151, International Monetary Fund. 1

Barro, R. and Lee, J.-W. (2010). A New Data Set of Educational Attainment in the World, 19502010. Journal of Development Economics, 104, 184-198. 4

Becker, S. O. and Woessmann, L. (2009). Was weber wrong? a human capital theory of protestant economic history. The Quarterly Journal of Economics, 124 (2), 531-596. 11

Bertola, G. (2010). Inequality, integration, and policy: issues and evidence from emu. Journal of Economic Inequality, 8 (3), 345-365. 1, 3

Biau, O., Dieden, H., Ferrucci, G., Friz, R. and Lindén, S. (2010). Consumers quantitative inflation perceptions and expectations in the euro area: an evaluation. Tech. rep., Mimeo. 4

Blanchflower, D. G. and Kelly, R. (2008). Macroeconomic literacy, numeracy and the implications for monetary policy. 1

Bogliacino, F. and Maestri, V. (2014). Increasing Economic Inequalities? In W. Salverda, B. Nolan, D. Checchi, I. Marx, A. McKnight, I. G. Tóth and H. van de Werfhorst (eds.), Changing Inequalities in Rich Countries: Analytical and Comparative Perspectives, Oxford: Oxford University Press, pp. 14-48. 3

- and Ortoleva, P. (2015). The Behavior of Other as a Reference Point. DOCUMENTOS DE TRABAJO - ESCUELA DE ECONOMA 013611, UN - RCE - CID. 4

Bouvet, F. (2010). Emu and the dynamics of regional per capita income inequality in europe. The Journal of Economic Inequality, 8 (3), 323-344. 1

Bowdler, C. and Nunziata, L. (2006). Trade Openness and Inflation Episodes in the OECD. Journal of Money, Credit and Banking, 38 (2), 553-563. 2

- and - (2007a). Inflation Adjustment and Labour Market Structures: Evidence from a Multicountry Study. Scandinavian Journal of Economics, 109 (3), 619-642. 2 
- and - (2007b). Trade Union Density and Inflation Performance: Evidence from OECD Panel Data. Economica, 74 (293), 135-159. 2

Brickman, P. and Campbell, D. T. (1971). Hedonic relativism and planning the good society. In M. H. Apley (ed.), Adaptation-level theory: A symposium, Michigan: Academic Press, pp. 287-305. 2

Bruni, L. (2009). Civil Happiness: Economics and Human Flourishing in Historical Perspective. Routledge. 2

Caporale, G. M. and Kontonikas, A. (2009). The euro and inflation uncertainty in the european monetary union. Journal of International Money and Finance, 28 (6), 954-971. 1

Cestari, V., Del Giovane, P. and Rossi-Arnaud, C. (2008). Memory for prices and the euro cash changeover: an analysis for cinema prices in Italy. In P. Del Giovane and R. Sabbatini (eds.), The Euro, Inflation and Consumers' Perceptions, Springer, pp. 125-156. 1

Del Giovane, P., Fabiani, S. and Sabbatini, R. (2008). What's behind 'inflation perceptions'? A survey-based analysis of Italian consumers. In P. Del Giovane and R. Sabbatini (eds.), The Euro, Inflation and Consumers' Perceptions, Springer, pp. 13-49. 2

- and Sabbatini, R. (2008). Perceived and measured inflation after the launch of the euro: explaining the gap in Italy. In P. Del Giovane and R. Sabbatini (eds.), The Euro, Inflation and Consumers' Perceptions, Springer, pp. 13-49. 1, 2

Di Tella, R., Haisken-De New, J. and MacCulloch, R. (2010). Happiness adaptation to income and to status in an individual panel. Journal of Economic Behavior $\&$ Organization, 76 (3), 834-852. 7

Duesenberry, J. S. (1949). Income, Saving and the Theory of Consumer Behaviour. Cambridge: Harvard University Press. 3

EC (2014). Joint EU Harmonised Programme of Business and Consumer Surveys. User guide, European Commission. 4

Ehrmann, M. (2006). Rational inattention, inflation developments and perceptions after the euro cash changeover. Working Paper Series 588, European Central Bank. 1, 4

Ferrer-i Carbonell, A. (2005). Income and well-being: an empirical analysis of the comparison income effect. Journal of Public Economics, 89 (5-6), 997-1019. 2

Fluch, M. and Stix, H. (2005). Perceived inflation in austria extent, explanations, effects. Monetary Policy 8 the Economy, (3), 2247. 1

Frank, R. H., Levine, A. S. and Dijk, O. (2014). Expenditure cascades. Review of Behavioral Economics, 1 (12), 55-73. 2

Gaiotti, E. and Lippi, F. (2004). Pricing behavior and the introduction of the euro: Evidence from a panel of restaurants in italy. Giornale degli Economisti, 63 (3-4), 491-526. 1

Genicot, G. and Ray, D. (2017). Aspirations and inequality. Econometrica, 85 (2), 489-519. 4

Heckman, J. J. (2000). Causal parameters and policy analysis in economics: A twentieth century retrospective. The Quarterly Journal of Economics, 115 (1), 45-97. 10

Herfindahl, O. C. (1950). Concentration in the Steel Industry. Ph.D. thesis, Columbia University. $4,5.1$

Hirsch, F. (1976). Social limits to growth. Cambridge: Harvard University Press. 3 
Hirschman, A. O. (1964). The paternity of an index. American Economic Review, 54, 761-762. 4, 5.1

Kahneman, D., Krueger, A. B., Schkade, D. A., Schwarz, N. and Stone, A. A. (2004). A survey method for characterizing daily life experience: The day reconstruction method. Science, 306 (5702), 1776-1780. 2

King, G., Honaker, J., Joseph, A. and Scheve, K. (2001). Analyzing incomplete political science data: An alternative algorithm for multiple imputation. American Political Science Review, 95 (1), 49-69. 18

LINDÉN, S. (2005). Quantified perceived and expected inflation in the euro area-how incentives improve consumers inflation forecasts. In Joint European Commission-OECD Workshop on International Development of Business and Consumer Tendency Surveys, Brussels. 8, 5.1

Malgarini, M. (2009). Quantitative inflation perceptions and expectations of italian consumers. Giornale degli Economisti, 68 (1), 53-80. 1

Marini, G., Piergallini, A. and Scaramozzino, P. (2007). Inflation bias after the euro: evidence from the uk and italy. Applied Economics, 39 (4), 461-470. 1

Mezulis, A. H., Abramson, L. Y., Hyde, J. S. and Hankin, B. L. (2004). Is there a universal positivity bias in attributions? a meta-analytic review of individual, developmental, and cultural differences in the self-serving attributional bias. Psychological Bulletin, 130 (5), 711-747. 5

Moon, Y. (2003). Dont blame the computer: When self-disclosure moderates the self-serving bias. Journal of Consumer Psychology, 13 (12), 125 - 137. 5

Nienues, J. (2010). Social Spending Generosity and Income Inequality: A Dynamic Panel Approach. IZA Discussion Papers 5178, Institute for the Study of Labor (IZA). 3

Oster, E. (2016). Unobservable selection and coefficient stability: Theory and evidence. Journal of Business 85 Economic Statistics, forthcoming. 17

Piketty, T. and Saez, E. (2003). Income Inequality In The United States, 1913-1998. The Quarterly Journal of Economics, 118 (1), 1-39. 3

Rubin, D. (1987). Multiple Imputation for Nonresponse in Surveys. New York: Wiley. A

Solt, F. (2009). Standardizing the world income inequality database*. Social Science Quarterly, 90 (2), 231-242. 4, A

Staiger, D. and Stock, J. H. (1997). Instrumental variables regression with weak instruments. Econometrica, 65 (3), 557-586. A

Stiglitz, J. E. (2011). Of the 1\%, by the 1\%, for the 1\%. Vanity Fair. 6

Stolper, W. F. and Samuelson, P. A. (1941). Protection and real wages. The Review of Economic Studies, 9 (1), 58-73. 16

Stutzer, A. (2004). The role of income aspirations in individual happiness. Journal of Economic Behavior \& Organization, 54 (1), 89 - 109. 2

Tóтн, I. G. (2014). Rivisiting Grand Narratives of Growing Inequalities: Lessons from 30 Country Studies. In W. Salverda, B. Nolan, D. Checchi, I. Marx, A. McKnight, I. G. Tóth and H. van de Werfhorst (eds.), Changing Inequalities and Societal Impacts in Rich Countries: Thirty Countries' Experiences, Oxford: Oxford University Press, pp. 11-47. 3 
Veblen, T. (1899). The Theory of the Leisure Class: An Economic Study of Institutions. MacMillan. 3

Woo, J., Bova, E., Kinda, T. and Zhang, Y. S. (2013). Distributional Consequences of Fiscal Consolidation and the Role of Fiscal Policy: What Do the Data Say? IMF Working Papers 13/195, International Monetary Fund. 1 
Figure 1: Measured and Perceived Inflation in the Euro Area

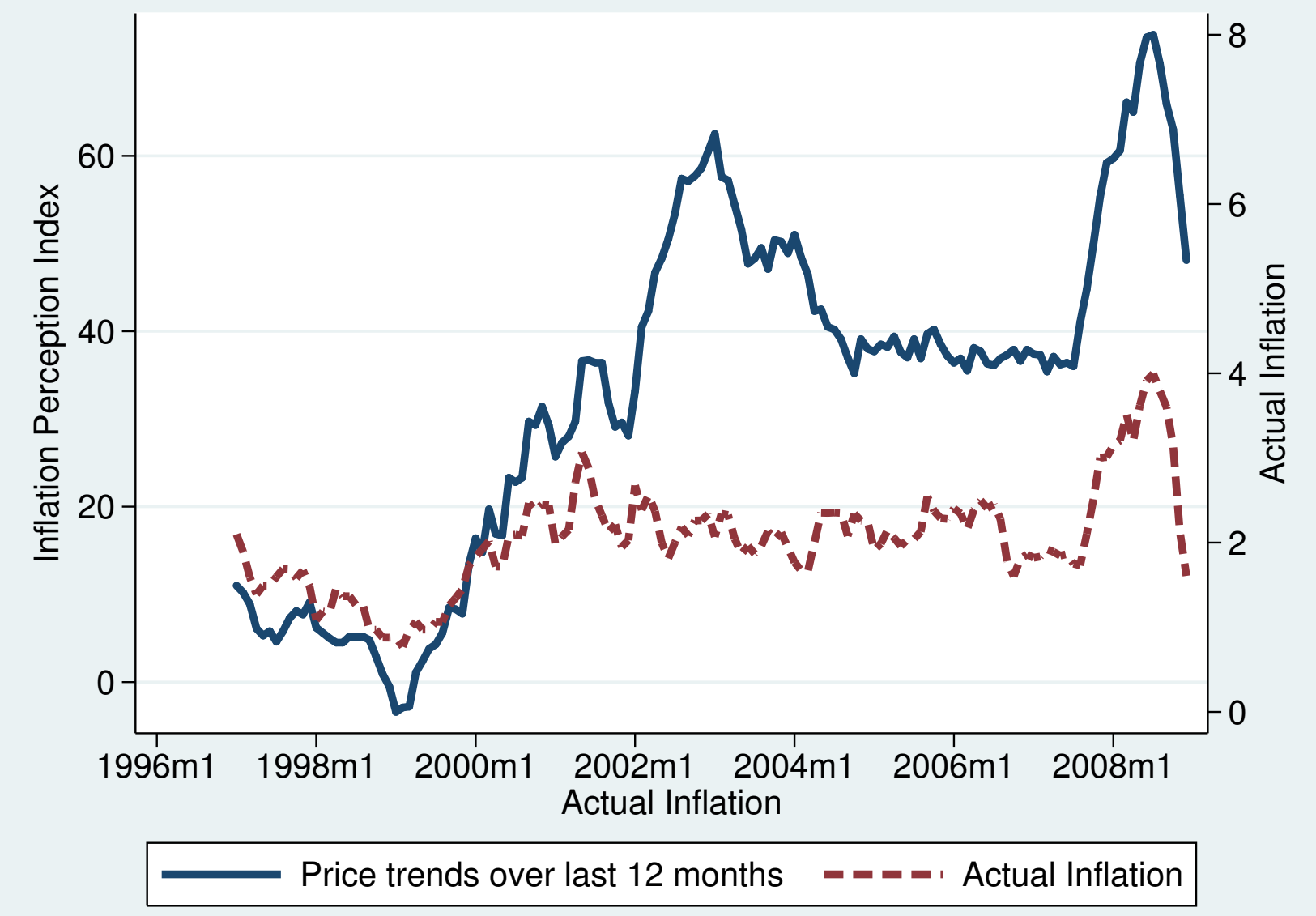

Left scale: difference in the weighted frequency of answers "price increased" versus "stable or decreased prices" in monthly surveys. Right scale: harmonised inflation rate y.o.y. Source: European Commission and Eurostat. 
Figure 2: Inequality and Inflation Mispercentions in Euro-15 Countries (1990-2008)

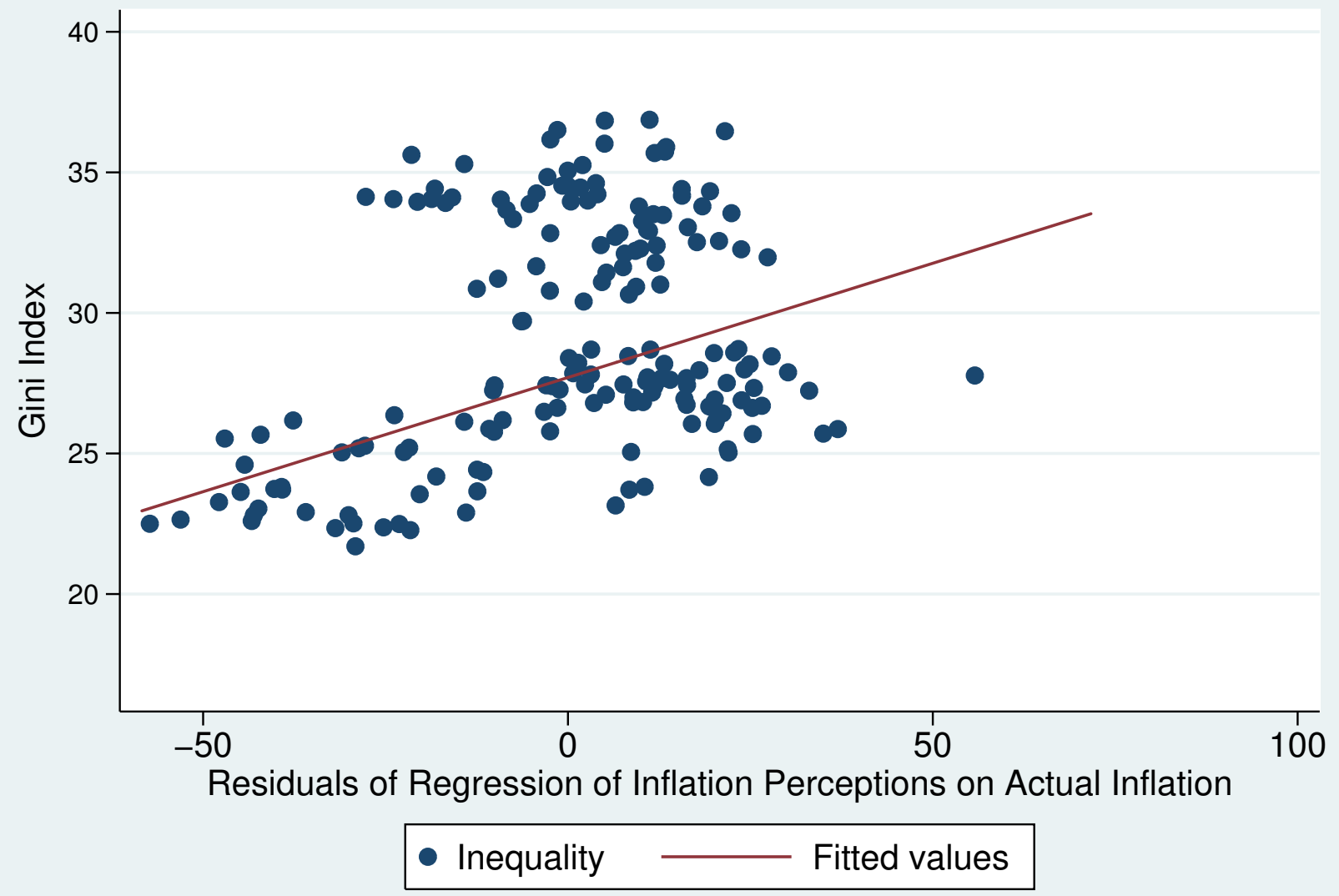

Source: Eurostat 
Figure 3: Inequality and Per Capita Social Expenditure in EU-15 Countries (1990-2008)

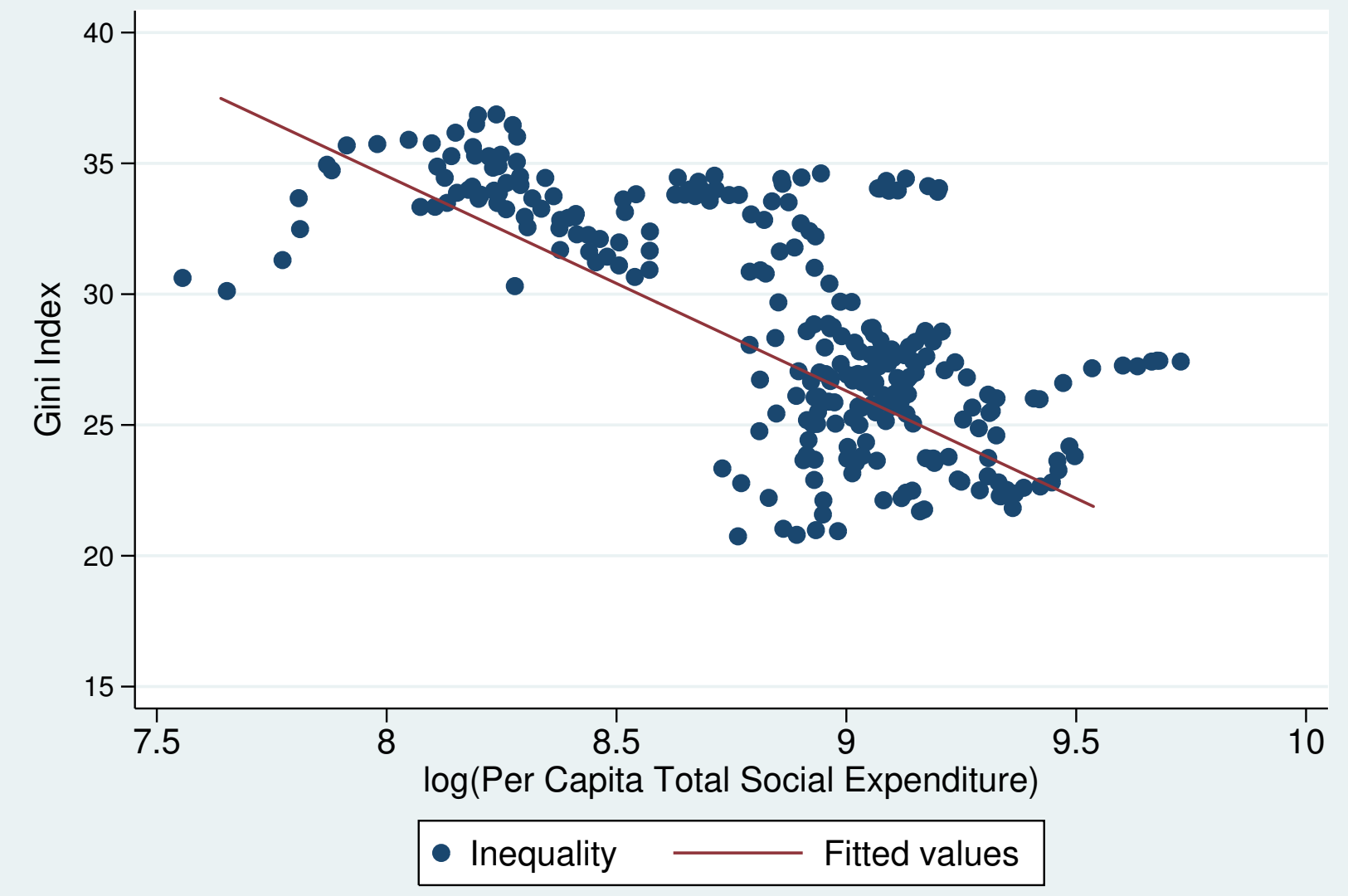

Source: Eurostat

Per capita social expenditure includes expenditure for sickness and disability, old age and survivors, housing and social exclusion, unemployment and families and children. 
Figure 4: Per Capita Social Expenditure in Euro Countries After Maastricht Treaty
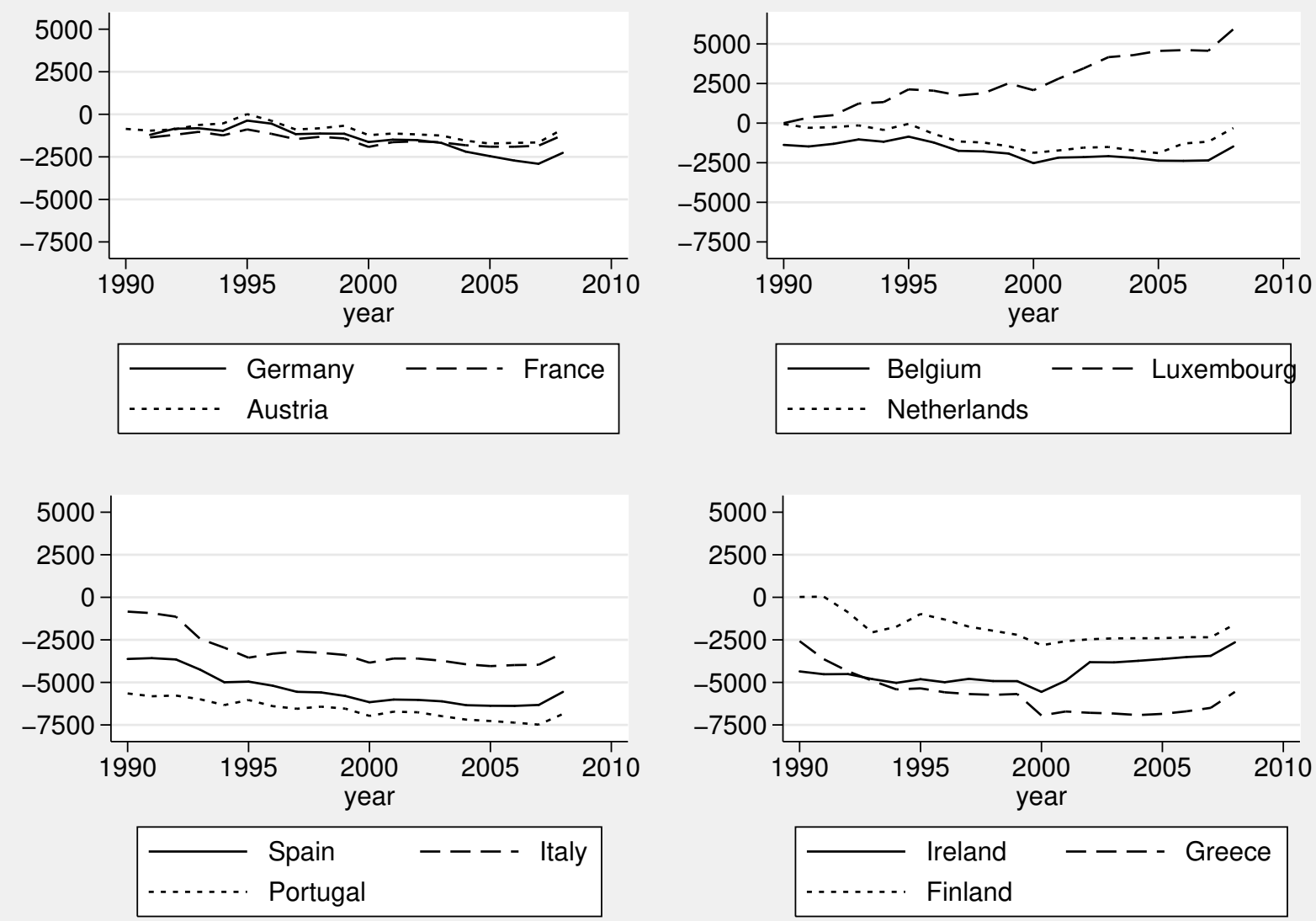

Difference between per capita social expenditure in Euro in the countries subject to the Maastricht Treaty budget constraints, and those that did not signed the treaty. The non-adopting countries average is calculated using data for Denmark, Sweden and the United Kingdom. Per capita social expenditure includes expenditure for sickness and disability, old age and survivors, housing and social exclusion, unemployment and families and children. 
Table 1: Summary statistics, by country

\begin{tabular}{|c|c|c|c|c|c|}
\hline Country & Infl.Perc & Actual Infl. & Saving Perc. & Inequality & Social Exp. \\
\hline \multirow[t]{2}{*}{ Austria } & 13.24 & 1.73 & 44.92 & 27.19 & 9155.31 \\
\hline & $(33.85)$ & $(0.72)$ & (13.63) & $(0.77)$ & $(484.26)$ \\
\hline \multirow[t]{2}{*}{ Belgium } & 39.12 & 2.04 & 31.75 & 25.55 & 7921.12 \\
\hline & $(17.48)$ & $(0.92)$ & $(37.57)$ & $(1.54)$ & $(868.34)$ \\
\hline \multirow[t]{2}{*}{ Denmark } & -21.29 & 2.01 & 66.84 & 23.21 & 11531.86 \\
\hline & (16.79) & $(0.68)$ & $(6.93)$ & $(1.32)$ & $(1264.71)$ \\
\hline \multirow[t]{2}{*}{ Finland } & -12.67 & 1.69 & 10.00 & 24.68 & 8117.98 \\
\hline & $(19.62)$ & (1.01) & $(13.84)$ & $(1.55)$ & $(682.02)$ \\
\hline \multirow[t]{2}{*}{ France } & 20.28 & 1.74 & 37.61 & 28.23 & 8331.38 \\
\hline & $(26.41)$ & $(0.69)$ & $(15.06)$ & $(0.45)$ & $(907.95)$ \\
\hline \multirow[t]{2}{*}{ Germany } & 33.77 & 1.57 & 45.27 & 27.44 & 8397.05 \\
\hline & $(17.91)$ & $(0.62)$ & $(6.44)$ & $(0.74)$ & $(449.95)$ \\
\hline \multirow[t]{2}{*}{ Greece } & 50.32 & 3.25 & -52.43 & 33.10 & 4139.55 \\
\hline & $(25.33)$ & $(0.57)$ & $(10.24)$ & $(0.87)$ & $(651.07)$ \\
\hline \multirow[t]{2}{*}{ Ireland } & 30.95 & 3.03 & 23.58 & 32.04 & 5335.34 \\
\hline & $(16.22)$ & (1.14) & $(13.23)$ & $(1.43)$ & (1767.69) \\
\hline \multirow[t]{2}{*}{ Italy } & 37.20 & 2.31 & 48.14 & 33.05 & 6584.77 \\
\hline & $(16.53)$ & $(0.48)$ & $(9.26)$ & $(1.24)$ & $(656.57)$ \\
\hline \multirow[t]{2}{*}{ Luxembourg } & 42.96 & 2.99 & 57.19 & 27.35 & 15477.10 \\
\hline & $(8.20)$ & $(0.69)$ & $(5.54)$ & $(0.12)$ & $(954.92)$ \\
\hline \multirow[t]{2}{*}{ Netherlands } & 27.69 & 2.26 & 61.55 & 25.55 & 8700.13 \\
\hline & $(18.92)$ & $(1.07)$ & $(3.84)$ & $(1.25)$ & $(854.19)$ \\
\hline \multirow[t]{2}{*}{ Portugal } & 40.83 & 2.72 & -39.55 & 34.69 & 3104.73 \\
\hline & $(12.31)$ & $(0.71)$ & $(13.41)$ & $(2.11)$ & $(685.74)$ \\
\hline \multirow[t]{2}{*}{ Spain } & 34.15 & 2.94 & 17.70 & 33.05 & 4294.96 \\
\hline & $(18.05)$ & $(0.70)$ & $(33.92)$ & $(1.69)$ & $(490.15)$ \\
\hline \multirow[t]{2}{*}{ Sweden } & -22.78 & 1.65 & 8.47 & 23.47 & 10250.83 \\
\hline & $(11.55)$ & $(0.80)$ & $(8.72)$ & $(1.35)$ & $(774.34)$ \\
\hline \multirow[t]{2}{*}{ United Kingdom } & 12.06 & 1.73 & 14.19 & 34.09 & 7603.58 \\
\hline & $(15.75)$ & $(0.73)$ & $(12.85)$ & $(0.32)$ & $(1715.54)$ \\
\hline \multirow[t]{2}{*}{ Total } & 21.32 & 2.21 & 26.30 & 29.01 & 7618.87 \\
\hline & $(28.79)$ & $(0.95)$ & $(35.63)$ & $(4.21)$ & $(2832.98)$ \\
\hline
\end{tabular}

All reported figures are sample averages and standard deviations (in brackets) calculated over the period 1990-2008. 


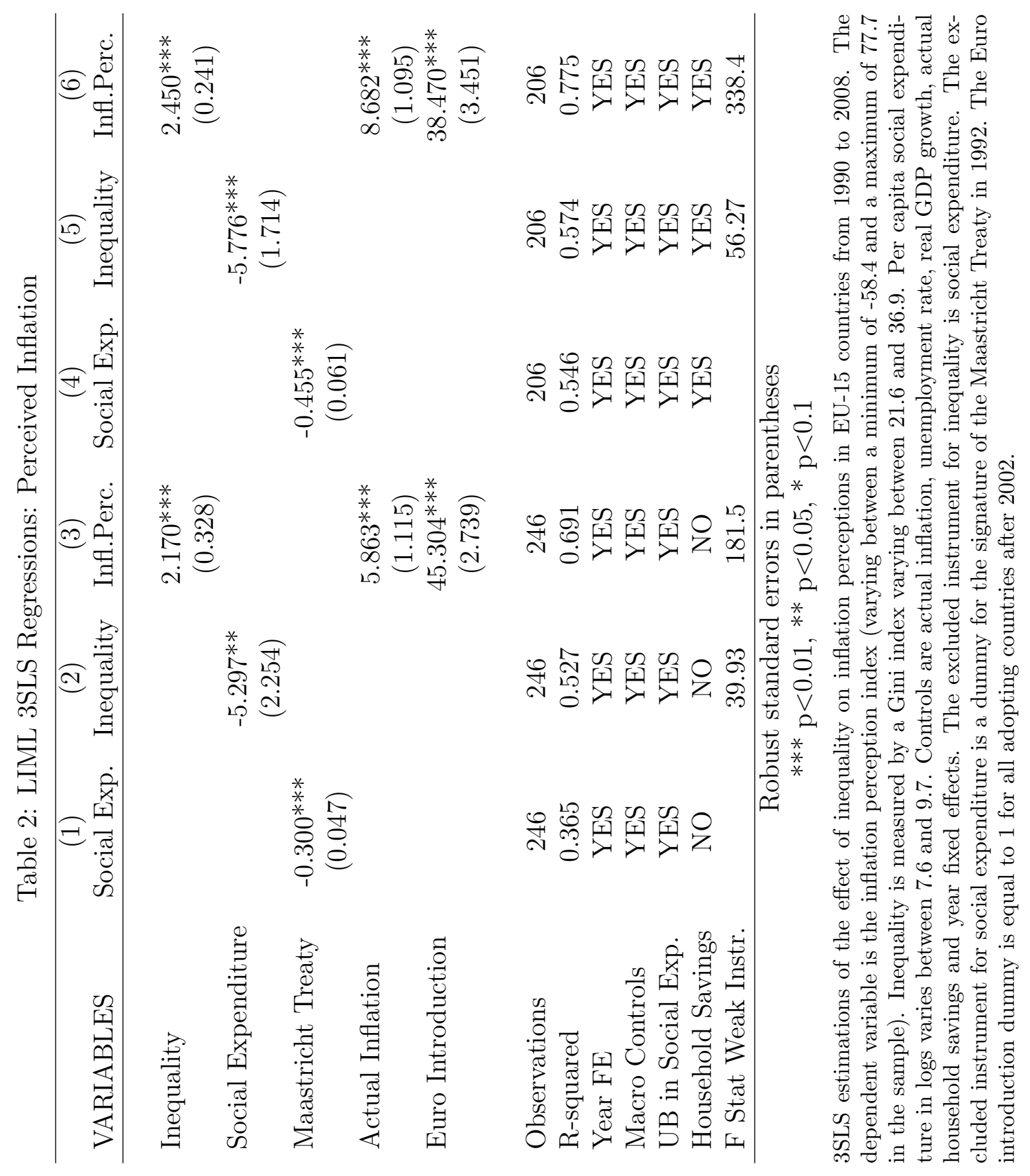


Table 3: LIML 3SLS Regressions: Perceived Inflation, Robustness

\begin{tabular}{|c|c|c|c|c|c|c|}
\hline VARIABLES & $\begin{array}{c}(1) \\
\text { Infl.Perc. }\end{array}$ & $\begin{array}{c}(2) \\
\text { Infl.Perc. }\end{array}$ & $\begin{array}{c}(3) \\
\text { Infl.Perc. }\end{array}$ & $\begin{array}{c}(4) \\
\text { Infl.Perc. }\end{array}$ & $\begin{array}{c}(5) \\
\text { Infl.Perc. }\end{array}$ & $\begin{array}{c}(6) \\
\text { Infl.Perc. }\end{array}$ \\
\hline Inequality & $\begin{array}{c}2.198^{* * *} \\
(0.347)\end{array}$ & $\begin{array}{c}1.895^{* * *} \\
(0.300)\end{array}$ & $\begin{array}{c}1.848^{* * *} \\
(0.315)\end{array}$ & $\begin{array}{c}2.359^{* * *} \\
(0.327)\end{array}$ & $\begin{array}{c}3.587^{* * * *} \\
(0.477)\end{array}$ & $\begin{array}{c}2.004^{* * *} \\
(0.321)\end{array}$ \\
\hline Actual Inflation & $\begin{array}{c}5.826^{* * *} \\
(1.146)\end{array}$ & $\begin{array}{c}10.210^{* * *} \\
(1.565)\end{array}$ & $\begin{array}{c}7.941^{* * *} \\
(0.993)\end{array}$ & $\begin{array}{c}6.205^{* * *} \\
(1.182)\end{array}$ & $\begin{array}{c}4.813^{* * *} \\
(1.504)\end{array}$ & $\begin{array}{c}9.399^{* * *} \\
(1.381)\end{array}$ \\
\hline Euro Introduction & $\begin{array}{c}45.282^{\text {*** }} \\
(2.730)\end{array}$ & $\begin{array}{c}44.047^{* * *} \\
(2.696)\end{array}$ & $\begin{array}{c}44.071^{* * *} \\
(3.046)\end{array}$ & $\begin{array}{c}41.652^{* * *} \\
(3.122)\end{array}$ & $\begin{array}{c}45.762^{* * *} \\
(3.635)\end{array}$ & $\begin{array}{c}33.724^{* * *} \\
(3.268)\end{array}$ \\
\hline Fixed Capital, \% GDP & & $\begin{array}{c}-0.379 \\
(0.365)\end{array}$ & & & & $\begin{array}{c}1.486^{* * *} \\
(0.522)\end{array}$ \\
\hline HH Index & & & $\begin{array}{c}6.892 \\
(44.538)\end{array}$ & & & $\begin{array}{c}28.001 \\
(67.005)\end{array}$ \\
\hline Education & & & & $\begin{array}{c}-0.005^{* * *} \\
(0.002)\end{array}$ & & $\begin{array}{c}-0.018^{* * *} \\
(0.002)\end{array}$ \\
\hline House Price Infl. & & & & & $\begin{array}{c}0.620^{* *} \\
(0.282)\end{array}$ & $\begin{array}{c}0.033 \\
(0.249)\end{array}$ \\
\hline Observations & 246 & 211 & 223 & 226 & 196 & 147 \\
\hline R-squared & 0.690 & 0.743 & 0.748 & 0.717 & 0.639 & 0.851 \\
\hline Year FE & YES & YES & YES & YES & YES & YES \\
\hline Macro Controls & YES & YES & YES & YES & YES & YES \\
\hline UB in Social Exp. & $\mathrm{NO}$ & YES & YES & YES & YES & YES \\
\hline F Weak Instr. 1st st. & 43.44 & 36.41 & 41.59 & 44.10 & 28.17 & 29.39 \\
\hline F Weak Instr. 2nd st. & 145.8 & 244.6 & 151.0 & 242.4 & 145.1 & 399.4 \\
\hline
\end{tabular}

Robust standard errors in parentheses

$$
\text { *** } \mathrm{p}<0.01,{ }^{*} * \mathrm{p}<0.05,{ }^{*} \mathrm{p}<0.1
$$

3SLS estimations of the effect of inequality on inflation perceptions in EU-15 countries from 1990 to 2008. The dependent variable is the inflation perception index (varying between a minimum of -58.4 and a maximum of 77.7 in the sample). Inequality is measured by a Gini index varying between 21.6 and 36.9. Per capita social expenditure in logs varies between 7.6 and 9.7. Controls are actual inflation, unemployment rate, real GDP growth and year fixed effects. The excluded instrument for inequality is social expenditure. The excluded instrument for social expenditure is a dummy for the signature of the Maastricht Treaty in 1992. The Euro introduction dummy is equal to 1 for all adopting countries after 2002 . 


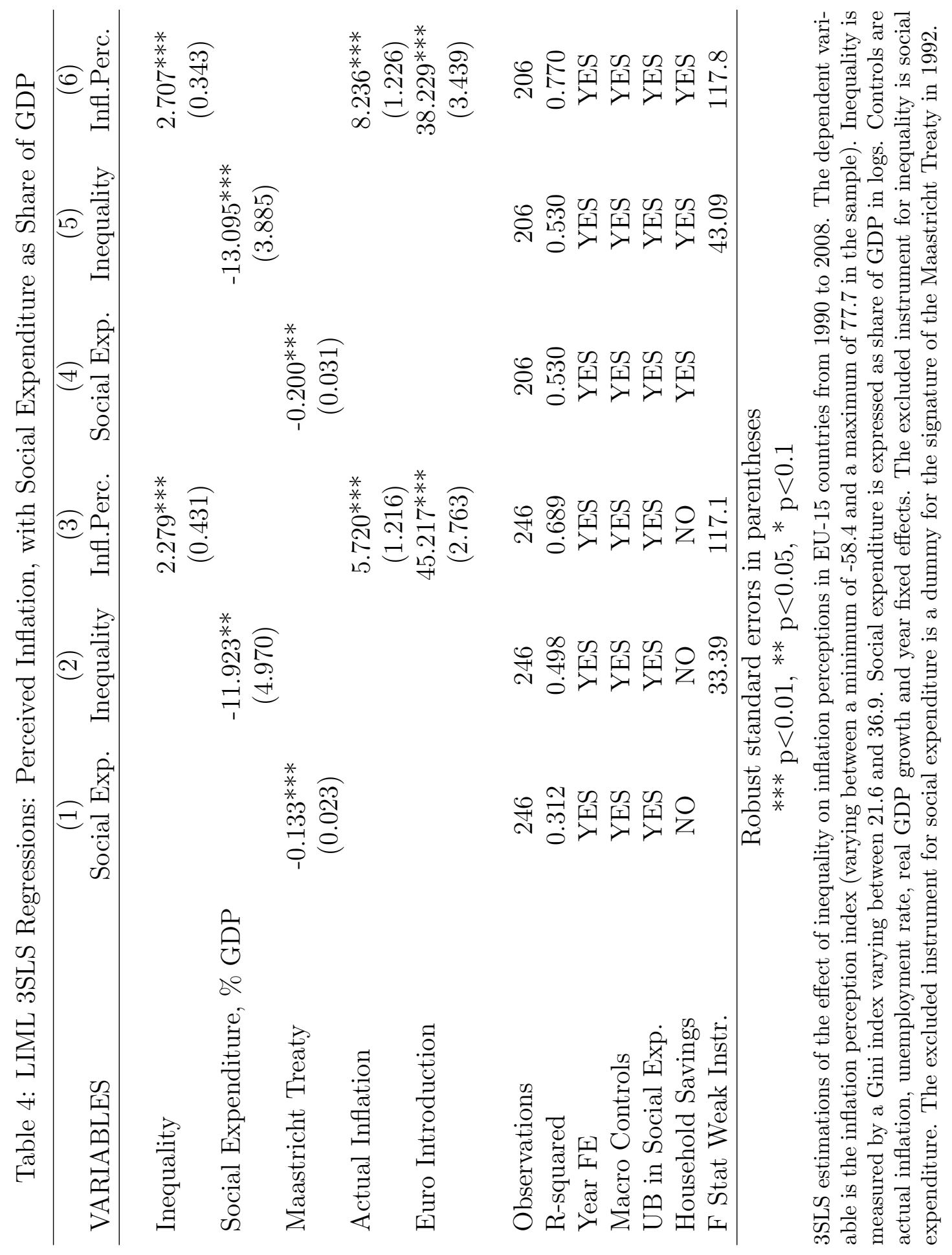


Table 5: LIML 3SLS Regressions: Perceived Savings

$\begin{array}{llllll}(1) & (2) & (3) & (4) & \text { (5) } & \text { (6) }\end{array}$
VARIABLES Social Exp. Inequality Infl.Perc. Social Exp. Inequality Infl.Perc.

Inequality

Social Expenditure

Maastricht Treaty $\quad-0.300 * * *$

$(0.047)$

Actual Inflation

Euro Introduction

Observations

R-squared

Year FE

Macro Controls

UB in Social Exp.

Household Savings

F Stat Weak Instr.

$-8.835^{* * *}$

(0.872)

$-5.297^{* *}$

(2.254)

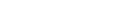

)

Social Exp. Inequality Infl.Perc. Social Exp. Inequality Infl.Perc.


Table 6: LIML 2SLS Regressions: Perceived Inflation

\begin{tabular}{lccccc}
\hline & $(1)$ & $(2)$ & $(3)$ & $(4)$ & $(5)$ \\
VARIABLES & Infl.Perc. & Infl.Perc. & Infl.Perc. & Infl.Perc. & Infl.Perc. \\
\hline & & & & & \\
Inequality & $6.898^{* *}$ & $9.302^{* * *}$ & $5.544^{* * *}$ & $13.658^{* * *}$ & $11.992^{* * *}$ \\
& $(2.774)$ & $(2.774)$ & $(1.832)$ & $(3.652)$ & $(2.105)$ \\
Actual Inflation & $7.599^{* * *}$ & $8.953^{* * *}$ & $7.089^{* * *}$ & $8.323^{* * *}$ & $10.134^{* * *}$ \\
& $(1.292)$ & $(1.278)$ & $(1.153)$ & $(1.347)$ & $(1.035)$ \\
Household Savings & & -0.669 & & & -0.847 \\
& & $(0.591)$ & & & $(0.535)$ \\
Euro Introduction & $25.737^{* * *}$ & $28.370^{* * *}$ & $23.416^{* * *}$ & $22.874^{* * *}$ & 4.547 \\
& $(3.686)$ & $(3.906)$ & $(4.045)$ & $(5.377)$ & $(6.036)$ \\
Education & & & $-0.009^{* *}$ & & $-0.036^{* * *}$ \\
& & & $(0.004)$ & & $(0.006)$ \\
House Price Infl. & & & & $1.470^{* * *}$ & $0.924^{* * *}$ \\
& & & & $(0.438)$ & $(0.267)$ \\
Observations & 246 & 206 & 226 & 196 & 154 \\
R-squared & 0.831 & 0.807 & 0.861 & 0.714 & 0.889 \\
Country FE & YES & YES & YES & YES & YES \\
Year FE & YES & YES & YES & YES & YES \\
Macro Controls & YES & YES & YES & YES & YES \\
UB in Social Exp. & YES & YES & YES & YES & YES \\
First Stage Coeff & -3.002 & -4.083 & -4.620 & -3.289 & -4.425 \\
First Stage SE & 0.824 & 0.950 & 0.832 & 0.958 & 0.826 \\
F Stat Weak Instr. & 13.26 & 18.46 & 30.86 & 11.79 & 28.73 \\
\hline
\end{tabular}

Robust standard errors in parentheses $* * * \mathrm{p}<0.01,{ }^{*} * \mathrm{p}<0.05,{ }^{*} \mathrm{p}<0.1$

2SLS estimations of the effect of inequality on inflation perceptions in EU-15 countries from 1990 to 2008. The dependent variable is the inflation perception index (varying between a minimum of -58.4 and a maximum of 77.7 in the sample). Inequality is measured by a Gini index varying between 21.6 and 36.9. Per capita social expenditure in logs varies between 7.6 and 9.7. Controls are actual inflation, unemployment rate, real GDP growth, actual household savings and country and year fixed effects. The excluded instrument for inequality is social expenditure. 


\section{APPENDIX}

\section{A Multiply Imputed Data Estimations}

The SWIID data on inequality is unique in providing information on inequality in different countries, calculated upon a uniform set of assumptions and definitions on harmonized microdata. The data construction is subject to a trade-off between comparability across countries and coverage of country/years cells, resolved through a multiple-imputation procedure (Solt, 2009). Such procedure introduces some noise in the inequality data, but one of the advantages of the SWIID dataset is that the researcher can appreciate the extent of such noise through the availability of 100 different imputed time series for inequality in each country. As a consequence, we can perform our analysis on SWIID data using two different approaches. The uncertainty introduced by multiple imputation can be resolved by simply averaging the 100 inequality series available for each country, as done in the tables above. Alternatively, we also estimated all models using Rubin (1987)'s approach, i.e. by estimating one separate model on each of the 100 inequality series, through multiple Monte Carlo simulations, and then pooling our set of 100 estimates by averaging the outcomes. ${ }^{18}$ Our findings are strongly consistent under the two approaches, and we do not find any appreciable difference in our estimates. If anything, the estimates obtained though Monte Carlo simulations tend to deliver larger point estimates and t-statistics. The F-statistics of weak instruments tend instead to be slightly smaller, but well above the threshold of 10 indicated by Staiger and Stock (1997) as the criterion for testing for instrument weakness when the parameters are just identified. ${ }^{19}$

\section{B Additional Tables}

\footnotetext{
${ }^{18}$ See also King et al. (2001).

${ }^{19}$ Results are not reported but are available upon request.
} 
Table A.1: Consumers Preferences on Being Rich, Have Money and Expensive Things

(1)

Imp. Expensive

Things

Difficult on Income

2nd decile

0.002

(0.007)

3rd decile

$-0.007$

$(0.007)$

4th decile

$-0.008$

(0.008)

5th decile

$-0.016^{* *}$

(0.008)

6th decile

$-0.011$

(0.008)

7th decile

0.002

(0.008)

8th decile

9th decile

0.008

(0.008)

10th decile

$0.077^{* * *}$

(0.009)

Observations

57,815

R-squared

0.077

Robust standard errors in parentheses

$$
* * * \mathrm{p}<0.01, * * \mathrm{p}<0.05, * \mathrm{p}<0.1
$$

Data from the European Social Survey collected every two years from 2002 to 2012 for the 15 major European countries. The dependent variable in columns (1) is a dummy variable equal to 1 if respondents consider themselves very much like, like, or somewhat like a person for whom it is "Important to be rich, have money and expensive things" (0 if a little like, not like, or not like such person at all). The data on income deciles are only collected for the years 2008, 2010 and 2012 for all countries excluding Austria. All regressions include demographic controls for age and gender, country dummies and year dummies. 
Table A.2: LIML 3SLS Estimates: Sensitivity to Euro Country Exclusion

\begin{tabular}{|c|c|c|c|c|c|c|c|c|}
\hline & (1) & $(2)$ & (3) & (4) & (5) & (6) & (7) & (8) \\
\hline VARIABLES & $\mathrm{BE}$ & DK & $\mathrm{DE}$ & IE & EL & $\mathrm{ES}$ & $\mathrm{FR}$ & IT \\
\hline \multirow[t]{2}{*}{ Inequality } & 2.134 & 1.540 & 2.324 & 1.921 & 2.104 & 2.126 & 2.243 & 2.353 \\
\hline & $(0.304)$ & $(0.316)$ & $(0.319)$ & $(0.391)$ & $(0.321)$ & $(0.345)$ & $(0.335)$ & $(0.333)$ \\
\hline \multirow[t]{2}{*}{ Actual Inflation } & 6.992 & 5.638 & 6.024 & 6.536 & 5.805 & 6.064 & 5.757 & 5.371 \\
\hline & $(1.040)$ & $(1.120)$ & $(1.150)$ & $(1.339)$ & (1.104) & $(1.244)$ & (1.167) & $(1.082)$ \\
\hline \multirow[t]{2}{*}{ Euro Introduction } & 42.782 & 46.292 & 44.247 & 46.167 & 44.422 & 44.831 & 44.215 & 45.938 \\
\hline & $(2.769)$ & $(3.046)$ & $(2.849)$ & $(2.636)$ & $(2.737)$ & $(2.811)$ & $(2.836)$ & $(2.788)$ \\
\hline Observations & 227 & 227 & 229 & 227 & 236 & 227 & 228 & 227 \\
\hline R-squared & 0.751 & 0.680 & 0.712 & 0.703 & 0.680 & 0.681 & 0.681 & 0.680 \\
\hline Year FE & YES & YES & YES & YES & YES & YES & YES & YES \\
\hline Macro Controls & YES & YES & YES & YES & YES & YES & YES & YES \\
\hline UB in Social Exp. & YES & YES & YES & YES & YES & YES & YES & YES \\
\hline \multirow[t]{2}{*}{ F Stat Weak Instr. } & 185.2 & 151 & 172.3 & 138.3 & 178.7 & 172.3 & 172.4 & 192.5 \\
\hline & (9) & (10) & (11) & $(12)$ & (13) & $(14)$ & (15) & \\
\hline VARIABLES & $\mathrm{LU}$ & NL & $\mathrm{AT}$ & $\mathrm{PT}$ & FI & $\mathrm{SE}$ & UK & \\
\hline \multirow[t]{2}{*}{ Inequality } & 2.254 & 2.332 & 2.242 & 3.181 & 1.845 & 2.062 & 2.198 & \\
\hline & $(0.341)$ & $(0.334)$ & $(0.334)$ & $(0.477)$ & $(0.346)$ & $(0.343)$ & $(0.366)$ & \\
\hline \multirow[t]{2}{*}{ Actual Inflation } & 5.748 & 5.515 & 5.582 & 6.483 & 5.522 & 5.702 & 5.717 & \\
\hline & $(1.112)$ & $(1.173)$ & (1.111) & $(1.349)$ & $(1.042)$ & $(1.111)$ & $(1.185)$ & \\
\hline \multirow[t]{2}{*}{ Euro Introduction } & 44.978 & 43.903 & 45.775 & 45.572 & 48.530 & 44.384 & 46.045 & \\
\hline & $(2.908)$ & $(2.791)$ & $(2.890)$ & $(2.915)$ & $(2.664)$ & $(3.412)$ & $(3.471)$ & \\
\hline Observations & 239 & 227 & 232 & 227 & 232 & 232 & 227 & \\
\hline R-squared & 0.685 & 0.712 & 0.689 & 0.672 & 0.716 & 0.650 & 0.696 & \\
\hline Year FE & YES & YES & YES & YES & YES & YES & YES & \\
\hline Macro Controls & YES & YES & YES & YES & YES & YES & YES & \\
\hline UB in Social Exp. & YES & YES & YES & YES & YES & YES & YES & \\
\hline F Stat Weak Instr. & 259.6 & 171 & 176.7 & 74.83 & 178.8 & 177.3 & 177.8 & \\
\hline
\end{tabular}

Robust standard errors in parentheses

3SLS estimations of the effect of inequality on inflation perceptions in EU-15 countries from 1990 to 2008. The dependent variable is the inflation perception index (varying between a minimum of -58.4 and a maximum of 77.7 in the sample). Inequality is measured by a Gini index varying between 21.6 and 36.9. Per capita social expenditure in logs varies between 7.6 and 9.7. Controls are actual inflation, unemployment rate, real GDP growth, and year fixed effects. The excluded instrument for inequality is social expenditure. The excluded instrument for social expenditure is a dummy for the signature of the Maastricht Treaty in 1992. Each equation is estimated dropping one country (indicated by column) from the sample. 